\title{
The existence of Asian small-clawed otter (Aonyx cinereus Illiger, 1815) in the UCPS Hydropower, Cianjur, West Java, Indonesia
}

\author{
ABDIEL PRAHA DIRGANTARA ${ }^{1}$, ERRI NOVIAR MEGANTARA ${ }^{1,2,3}$, TEGUH HUSODO ${ }^{1,2,3, \boldsymbol{v}}$, \\ PUPUT FEBRIANTO ${ }^{1}$, INDRI WULANDARI ${ }^{1,2,3}$, SYA SYA SHANIDA $^{1}$ \\ ${ }^{1}$ Center of Environmental and Sustainable Sciences, Directorate of Research, Community Services and Innovation, Universitas Padjadjaran. Jl. Sekeloa, \\ Coblong, Bandung 40132, West Java, Indonesia. Tel.: +62-22-2502176, `email: teguhhusodo2@gmail.com \\ ${ }^{2}$ Program of Environmental Science, School of Graduates, Universitas Padjadjaran. Jl. Dipati Ukur No. 35, Bandung 40132, West Java, Indonesia \\ ${ }^{3}$ Department of Biology, Faculty of Mathematics and Natural Sciences, Universitas Padjadjaran. Jl. Raya Bandung-Sumedang KM 21, Jatinangor, \\ Sumedang 45363, West Java, Indonesia
}

Manuscript received: 8 September 2021. Revision accepted: 24 September 2021.

\begin{abstract}
Dirgantara AP, Megantara EN, Husodo T, Febrianto P, Wulandari I, Shanida SS. 2021. The existence of Asian small-clawed otter (Aonyx cinereus Illiger, 1815) in the UCPS Hydropower, Cianjur, West Java. Biodiversitas 22: 4391-4401. Little information about the existence of small-clawed otters (Aonyx cinereus) in Indonesia is available. Small-clawed otter is the top predator and biological indicator of wetland health. However, the small-clawed otter population in the world has decreased due to anthropogenic factors. This study aims to reveal 1) estimate the population size of small-clawed otters and 2) the small-clawed otter signs at the UCPS Hydropower construction site, Cianjur, West Java. This study used a qualitative approach in February-April 2017. Sign surveys (feces, footprints, leftovers, and dens) and camera trapping were applied in this study. There were 32 signs with details of 21 feces, eight footprints, and three dens. The estimation of small-clawed otter population size at UCPS Hydropower ranges from 5-14 individuals in total scattered in the Citali-Cisokan, Cilengkong, and Cirumamis rivers. In addition, the discovery of infant and bedding repair activities shows that the habitat in the UCPS Hydropower area supports the daily needs of small-clawed otters, especially in terms of breeding and shelter. Further studies are needed regarding the impact of the UCPS Hydropower construction on the existence of small-clawed otters, especially in the overlapping between small-clawed otter habitat and the UCPS Hydropower construction sites, by monitoring and making wildlife management policies.
\end{abstract}

Keywords: Cisokan, sign survey, small-clawed otter

Abbreviations: UCPS: Upper Cisokan Pumped Storage, PLN: State Electricity Company

\section{INTRODUCTION}

Otters are the top predators in many freshwater ecosystems and serve as indicators of healthy aquatic environments (Kruuk 2006). Of the 13 extant species of otters globally, the Asian small-clawed otter (Aonyx cinereus) is the smallest (Hussain et al. 2011), rarely weighing more than $5 \mathrm{~kg}$. Globally, the small-clawed otter is widely distributed from India throughout South Asia across Bangladesh, Myanmar, Thailand, Indonesia, and Malaysia and from Southeast Asia to the Philippines, Taiwan, and eastern and southern China in the north (Hussain et al. 2011). In Indonesia, apart from the smallclawed otter, there are three other otter species: the Eurasian Otter Lutra lutra, hairy-nosed otter Lutra sumatrana, and the smooth-coated otter Lutrogale perspicillata (Gomez and Shepherd 2018).

In West Java, the typical habitats of the Asian smallclawed Otter are wetland systems having pools and stagnant water, including shallow stretches, with a depth less than one meter, such as tidal pools, mangroves, freshwater swamps, and meandering rivers. In West Java, its presence is positively associated with slow-flowing and stagnant broad rivers and smaller streams, depicting a distinct decline in preference from slow to deep-water bodies. They also use shallow, fast-flowing mountain creeks narrower than 5 meters, mainly when the course of the streams includes natural pools. They chose slowflowing irrigation channels thinner than 2 meters and with varied, moderate, or low vegetation in rice fields (UNEPWCMC 2021). Rice fields are an inundated aquatic ecosystem that supports various aquatic animals (Che et al. 2017). Small-clawed otters prefer moderate and low vegetation structures in riverine systems, though it was also observed from banks with inadequate vegetation cover (Wright et al. 2015).

There is little information on wild otter populations in Indonesia. Still, We believe that all four species are in decline due to increasing loss and degradation of suitable habitat, impacts from environmental pollution, human-otter conflicts, and poaching for trade (Gomez and Shepherd 2018). Indonesia is currently experiencing human overpopulation; hence, increased food production through agricultural modernization is unavoidable. Natural wetlands have been disappearing rapidly because of their conversion to palm oil plantations (Margono et al. 2014). A previous study showed that $A$. cinereus is considered vulnerable status according to the IUCN Redlist due to 
declining populations resulting from habitat loss and land exploitation (Hussain et al. 2011). Since 2019, the status of small-clawed otters in CITES has been upgraded from Appendix II to Appendix I (Okamoto et al. 2020; UNEPWCMC 2021). According to Glatston and Duplaix (2020), illegal trade is hard to control because it is difficult to trace an individual's origin or identify the species. According to the Act of the Republic of Indonesia No. P.106 of 2018 concerning the species of protected plants and animals, of the four species of otters, only small-clawed otters have not been protected in Indonesia. Small-clawed otters are considered indicator species of healthy freshwater ecosystems (Kruuk 2006) and flagship species for freshwater conservation in some regions (Cianfrani et al. 2011).

The lack of information on small-clawed otters is one reason why this study is essential to reveal the latest information on small-clawed otters, especially at the UCPS (Upper Cisokan Pumped Storage) Hydropower construction site, Cianjur, West Java. PT PLN (Persero), the Indonesian State-owned power company, is preparing to construct the UCPS Hydropower plant with a $1040 \mathrm{MW}$ pumped-storage hydropower in the Cirumanis and Cisokan Rivers West Java. PT PLN is committed to sustainability and consistently seeks to balance economic, social, and environmental performances to manifest the 'triple bottom lines' philosophy to make sustainable business growth (Husodo et al. 2019).
Several previous studies have been conducted, such as Melisch et al. (1994), Aadrean and Usio (2017), Aadrean and Usio (2020), and Andeska et al. (2021) in Indonesia. Information regarding the existence of small-clawed otters in the UCPS hydropower area is also minimal. Besides that, Cisokan is a non-conservation area, so there needs to be a small-clawed otter conservation effort in the Cisokan. Basic information is required about the existence of a small-clawed otter in Cisokan. Based on this background, the objective of this study is to reveal 1) estimate the population size of small-clawed otters and 2) the smallclawed otter signs at the UCPS Hydropower construction site, Cianjur, West Java.

\section{MATERIALS AND METHODS}

\section{Study area}

The study was conducted for two months (FebruaryApril 2017) during the rainy season. The study was conducted on three rivers, including the Citali-Cisokan, Cilengkong, and Cirumamis Rivers, with 179.83 ha (Figure 1). The Cisokan river originates from a forest upland area (maximum elevation of about $2000 \mathrm{~m}$ asl). After exiting the project area, the Cisokan waters flow towards the north, feed into the existing Waduk Jangari and Waduk Jatiluhur reservoirs, and eventually into the Java Sea (Meijaard and Ferguson 2014).

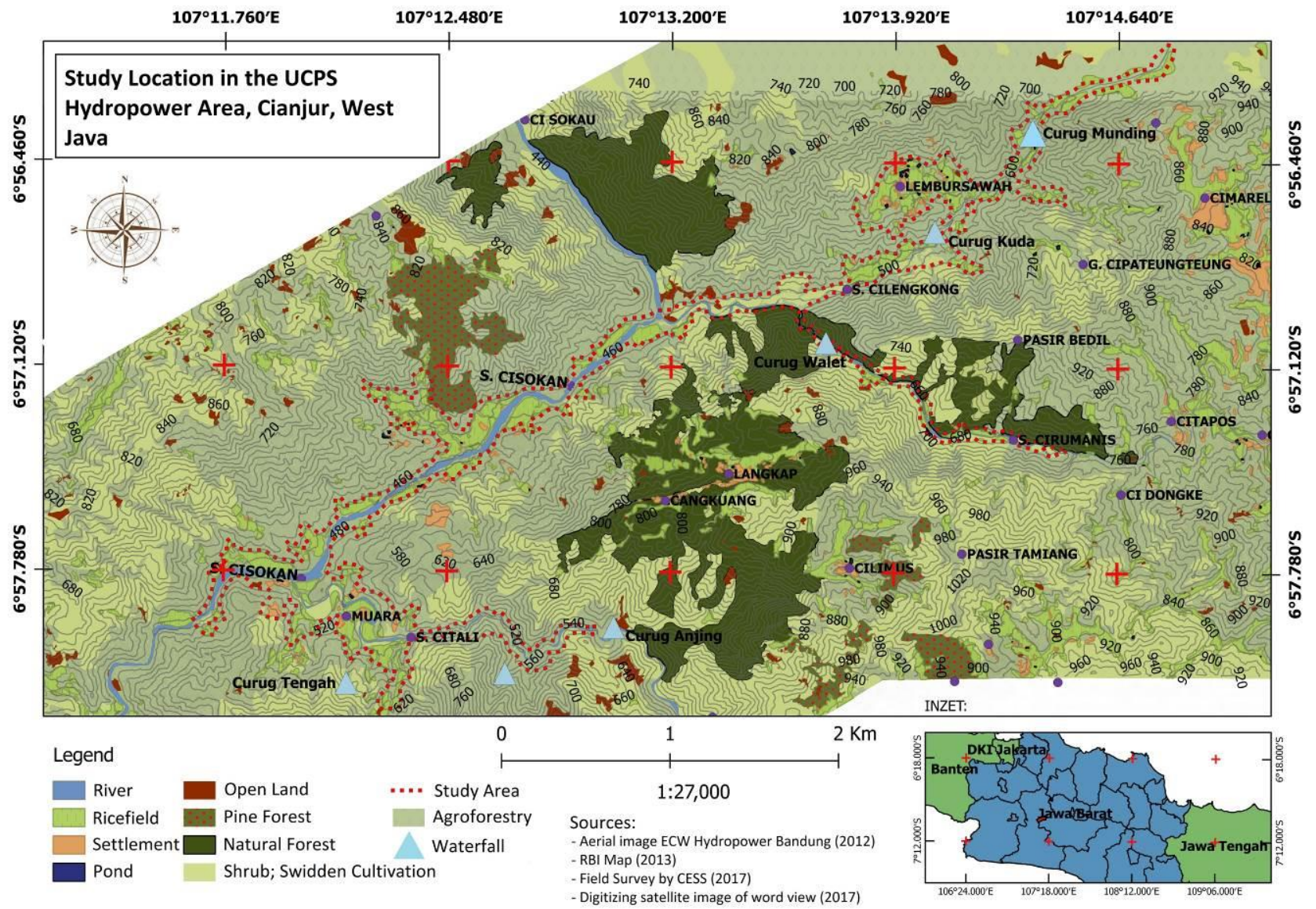

Figure 1. Study location in the Cisokan Hydropower, Cianjur, West Java, Indonesia 
Administratively, the construction of UCPS Hydropower and its infrastructure covers 720 ha (Meijaard and Ferguson 2014) in West Bandung and Cianjur. The scope of the UCPS Hydropower plan consists of the construction of a major powerhouse, surge tank, switchyard, upper and lower dam); 2) the access road; 3) inundation areas of the upper and lower dam; 4) transmission lines and quarry and potential landslide areas (Meijaard and Ferguson 2014). PLN company is building a UCPS Hydropower plant with a capacity of $1040 \mathrm{MW}$ in West Java with two dams, each with a 10.000.000 $\mathrm{m}^{3}$. Water will be released through the turbine from the upper reservoir to the lower reservoir to generate electricity during daily peak loads (05.00 p.m.-11.00 p.m.) The water collected from the reservoir will be pumped to the upper reservoir at the baseload or outside the daily peak load (00.30 a.m.-09.30 a.m.) using electrical energy supplied from the baseload of coal power plants.

The upstream dam is located on the Cirumamis River with a height of $75.5 \mathrm{~m}$, a catchment area of $10 \mathrm{~km}^{2}$, and a reservoir water surface area (highest water elevation) of 80 ha, with tidal fluctuations as high as $19 \mathrm{~m}$. The dam will be built with compacted concrete. The downstream dam located in Cisokan has a height of $98 \mathrm{~m}$ with a catchment area of $355 \mathrm{~km}^{2}$, a reservoir water surface area (highest water elevation) of 260 ha, and tide fluctuations as high as $4.5 \mathrm{~m}$. the generation capacity is $1040 \mathrm{MW}$ with a pumping capacity of $1100 \mathrm{MW}$ using an underground powerhouse. The tunnel will connect the powerhouse with the two reservoirs. The switchyard and administration building will complete the hydropower complex (LPPM Unpad 2014 unpublished).

Two twin transmission lines of $15.5 \mathrm{~km}$ and $15.9 \mathrm{~km}$ will connect the UCPS Hydropower with SUTET (Extrahigh Voltage Air Line) Cibinong-Saguling to the north. In the initial inundation, most of the water in the catchment will be drained through bottom outlets or spillways, and only water at the top of the reservoir is kept on hold to cover water loss due to evaporation. A new $27.5 \mathrm{~km}$ road will be built as the entrance to the project site and is $7 \mathrm{~km}$ long, while the $7 \mathrm{~km}$ existing road will be repaired. The Gunung Karang Quarry will be used as an aggregate and foundation material for dam construction. A $20 \mathrm{kV}$ distribution network will be installed before construction and will assist with constructing the power plant (LPPM Unpad 2014, data not shown).

\section{Procedures}

This study used a qualitative approach. Data was collected through sign surveys (feces, footprints, leftovers, dens) and camera trapping. Coordinates of otter records were recorded using a global positioning system (Fei and Chan 2017).

\section{Sign survey}

The sign survey data collection was carried out for 32 days. The survey was repeated twice (two sides of the river). The survey was conducted near water flows, such as paddy fields, irrigated rivers, small rivers, water flows around waterfalls (Curug), the edge of large rivers, and water flows around ponds. Hussain et al. (2011) said that small-clawed otters use various natural and humanmodified land, including peat swamps, rivers, streams, mangrove forests, rice fields, ditches, and fish ponds. Small-clawed otters prefer narrow streams, shallow, and high-elevation rather than deep, large rivers, and lowelevation regions in a protected wetland area in India (Perinchery et al. 2011; Raha and Hussain 2016). When small-clawed otters use human-altered landscapes, such as coffee and tea plantations adjacent to protected areas, latrine site (feces) occurrence is associated with riparian vegetation and the availability of potential refugees (e.g., boulders and fallen logs) (Prakash et al. 2012). Although environmental characteristics of the small-clawed otter latrine sites have been reported for human-altered landscapes (Prakash et al. 2012), such characteristics have yet to be investigated based on visitation frequency.

We identified and measured the small-clawed otter signs. Footprint identification using the guidelines of van Strien (1983) and Melisch et al. (1994). The morphometric measurement parameters of the footprint, including the length and width of the fore-foot and hind-foot, length of the step, stride, and straddle. Another parameter is feces compositions. We observed and broke them apart and recorded what composition was in them. Small-clawed otters are carnivores that primarily prey on aquatic animals, such as crabs, fish, frogs, arthropods, mammals, and snails (Hon et al. 2010). In addition, other parameters, namely the feces condition that is bolus-form, spread-form, or mixedform. The age of the feces, less than one day, is indicated as feces that are slimy, brown to black, and have a strong fishy smell. After one day is characterized as dry (not slimy) feces due to sun exposure. According to Green et al. (2015); Barocas et al. (2016), small-clawed otters use latrines (mammals scent marks with feces) for activities other than scent marking. For example, the latrine sites of Lontra canadensis are used to delineate territories and serve as meeting places or social information hubs among small groups. Identification of active and inactive dens is based on Kruuk (2006) that small-clawed otter uses rock gaps, earthen holes, and holes between wood roots as places for dens.

\section{Camera trapping}

We used five trail camera units: two Bushnell Trophy Cam 119537 and three Bushnell Trophy Cam 119446. The camera trap was deployed for 19-24 days. The camera traps were set in hybrid mode (photo and video) for 24 hours/day with a resolution of $8 \mathrm{MP}$. The photo mode setting was set to capture three images in one shot with a one-second interval. The video mode setting uses 10 seconds per recording with a resolution of 720 p. Sanghamithra and Nameer (2018), the camera automatically recorded the images' date and time of exposure.

The camera trap was placed close to the small-clawed otter signs. The camera trap was set in an entirely open area without any other objects or trees blocking it. According to Jansen et al. (2014), the camera was positioned parallel to 
the ground so that the line horizon was right in the center of the image. Installation was deployed by tying the camera to a tree trunk or wood vertically with an average height of 1.4 meters from the ground, and the distance from the lens to the object ranges from 1.6 meters (Hon et al. 2010). The camera trap installation can be adjusted based on the relatively small size of the small-clawed otter, the river water level that could rise quickly, the condition of the rocky river with a heavy flow, the rainy season, and avoiding damage from water.

\section{Data analysis}

The study was analyzed descriptively qualitatively. The population size estimation was calculated based on the camera trap documentation and signs from the CitaliCisokan, Cilengkong, and Cirumamis rivers. The results of the sign survey data analysis showed the relative number of small-clawed otter individuals. At the same time, the camera trap captured the exact number of small-clawed otter individuals, which proved and strengthened the analysis results. An estimate of the individuals' number was obtained in each river.

If the camera trap installation got nothing, data analysis from the sign survey estimates the number of small-clawed otter individuals by considering the most often found signs. The barriers, waterfalls (curug), as a natural geographical barrier, and the heavy water flow in large rivers are considered for determining the number of small-clawed otter individuals, causing those barriers to limit the movement of animals in a short time.

Determination of individuals through footprints is conducted using several parameters: footprint size, footprint direction, piled footprints, number of tracks, length of the step, stride and straddle, and soil substrate. If food remains are found, it is usually not far from where the footprints were found.

Determination of individuals through feces is conducted, including the feces size and the diameter of the latrine site. The first assumption is that if the feces is found outside the latrine site with the characteristics of the feces that are bolus-form and is found more than one feces close to each other, it is estimated that there will be one individual. Feces laying patterns and the presence of footprints around them is considered too. The second assumption, if feces is found in a latrine site with smeared scat, it is estimated that there are at least two individual of the small-clawed otters. The estimated number of individuals can be increased based on the size of the latrine site diameter by considering feces. This assumption is obtained from the habits of the small-clawed otter group who defecate at the latrine site and return to that location regularly and periodically (Kruuk 2006). The active den can be inhabited by at least two individuals, based on the characteristics of small-clawed otter groups and pairs (Kruuk 2006).

\section{RESULTS AND DISCUSSION}

The Asian small-clawed otters were found in the CitaliCisokan River, the Cilengkong River, and the Cirumamis River in the UCPS Hydropower area (Figure 2). Thirty-two signs of the small-clawed otter were found, including 21 feces, eight footprints, and three dens (Table 1), and the camera trap produced 146 photos and 203 videos (349 documents) with a total effort of 153 trap nights (Table 5).

The small-clawed otter presence location at UCPS Hydropower can be seen in Figure 2. Based on Table 4, a small-clawed otter's existence is primarily found in paddy fields and agroforestry. Small-clawed otters use paddy fields and agroforestry to meet their daily needs, such as shelter, dens, and a source of prey. According to Kanchanasaka and Duplaix (2011), rice field landscapes of some Southeast Asian countries, such as Malaysia, Thailand, Philippines, and Indonesia. Small-clawed otters use paddy fields as foraging and latrine sites. Paddy fields are an inundated aquatic ecosystem that supports various aquatic animals (Che et al. 2017).

Small-clawed otters' feces were found to have varying shapes, conditions, and compositions (Table 1). The majority of feces were spread-form $(52.6 \%)$, followed by bolus-form $(44.7 \%)$ and mixed-form $(2.6 \%)$. Feces found more than other signs because feces could be long-lasting. The small-clawed otter habit tends to choose open areas higher than river flow and return to use them within a certain period (Kruuk 2006). In addition, small-clawed otters' feces have unique characteristics, so they were easy to find during the study. In addition, $55.26 \%$ of the smallclawed otter feces was found to be slimy, while $44.74 \%$ were found to be dry (Figure 3A).

Based on the feces composition, most of the composition consisted of crabs $(94.7 \%)$, while the rest consisted of crabs and fish. In Cambodia, the previous study of Hon et al. (2010) that a small-clawed otter consumes crabs as its dominant prey. Based on the observation that crabs are easily found in rice fields and river flow. In peninsular Malaysia showed insects as a dominant food (Abdul-Patah et al. 2014). The composition of insects in the diet is positively related to temperature. The amount of frogs in otter diets is also positively associated with temperature (Andeska et al. 2021). Most otter species are generalists (Timm-Davis et al. 2015), and their diets reflect the local abundance of food (Almeida et al. 2012; Krpo-Ćetković et al. 2019).

In this study, small-clawed otter footprints were found less frequently than feces (Table 1). The feces are not longlasting because it is quickly erased by rainwater, river flow, and rising river water surface. Small-clawed otter footprints were found to vary in size. The results of morphometric measurements can be seen in Table 2 . The difference in the footprint size could be affected by the substrate which the small-clawed otter passes. Wet soil substrate could make the footprint size slightly larger than the original size, while the slightly dry and dense soil substrate could cause the footprints not fully printed, making it difficult to measure and identify. 


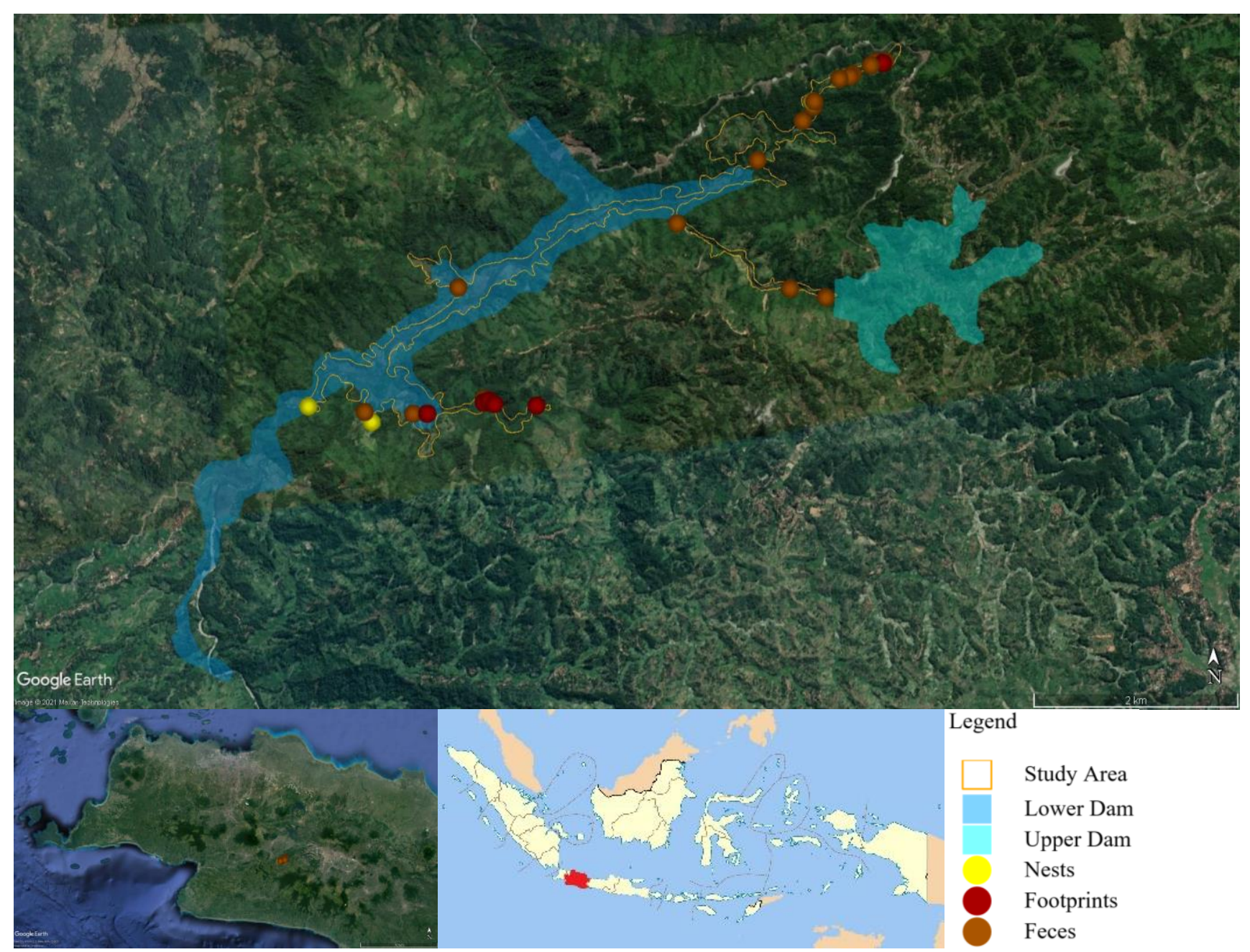

Figure 2. The distribution of small-clawed otter signs in UCPS Hydropower, West Java, Indonesia. Source: Google Earth (2021)

There were two types of dens: active and inactive dens (Table 1 and Table 3). The active den included footprints and wet and slimy feces around the den, found almost every day. In addition, the vegetation leading to the dens is getting more open. Some of the plants were found withered and broken. Vines were found around the den with their stems broken and leaves wilted from being trampled and crushed. Similar to Kruuk (2006) previous study, the smallclawed otter dens entrance characteristics often appear worn out. The entrance looks clean, but soil, rocks, or trees seem to be eroded due to friction of its body. Another characteristic of an active den includes branches, leaves, and stems of Lantana camara in front of the dens used as a sleeping mat. Similar activity was also observed in Lutra lutra in Scotland (Kruuk 2006).

Until the last recording on March 6, it was assumed that the group of small-clawed otters would remain in the den for the next few weeks/months if no disturbance would threaten the presence of the small-clawed otter. In addition, the presence of the infant was observed when the mother carried it out and into the den by biting its upper neck. The infant is also observed when exploring the area in front of the den. Besides, parents assist in its movement. Through the camera trap, parents brought the infant in-out of the den several times, at 05.32 p.m. (February 14); 04.52 p.m. and 00.02-01.38 a.m. (February 22); 05.12 p.m. (March 2); and 06.75-07.01 p.m. (March 3). According to Hussain et al. (2011), an infant will explore den holes at ten weeks of age, then begin learning to swim after three months of age with the mother's assistance.

On March 6, it was recorded that a small-clawed otter was inserting the leaves and stems of the Lantana camara into the den alternately. These leaves and stems are used to repair the sleeping mat in the den. Previously, the activity of inserting plant leaves and branches had been carried out three times, including at 04.10 p.m.-04.14 p.m. on February 23; at 04.49 p.m.-04.57 p.m. on February 24; and at 05.09 p.m.-05.14 p.m. on March 3. The leaves and stems are taken by taking the leaves and stems with the front legs. Then they are pulled and cut into smaller parts using teeth and brought into the den. Based on the observations of Wright (2005), the bamboo stalks taken by small-clawed otters are used as sleeping mats by lowering the stem first using the front legs and then cutting them using the teeth. 
According to Wright (2005), the intensity of activity to repair sleeping mats will increase two weeks before an individual female gives birth or has a baby in the den. In a previous study, small-clawed otters used other plants as sleeping mats, such as bamboo stalks, dry leaves, and undergrowth. From this statement, it can be assumed that this small-clawed otter group often repairs their sleeping mats because they have an infant. Within 12 days, the small-clawed otter repaired the sleeping mats three times.

Generally, walking out of the den is carried out in the afternoon (nocturnal) and returns to the den in the morning (crepuscular). This activity pattern indicates that this animal is classified as nocturnal and crepuscular. Similarly, Menzies and Rao (2021) said that small-clawed otters are predominantly nocturnal and crepuscular species.
Table 2. Measurement of small-clawed otter footprints

\begin{tabular}{lccc}
\hline Parameter & $\begin{array}{c}\text { Number of } \\
\text { data }\end{array}$ & $\begin{array}{c}\text { Measuring } \\
\text { range }(\mathbf{c m})\end{array}$ & $\begin{array}{c}\text { Average } \\
(\mathbf{c m})\end{array}$ \\
\hline Fore-foot & & & \\
Length & 9 & $4.82-5.93$ & $5.25 \pm 0.38$ \\
Width & 9 & $3.64-4.54$ & $3.93 \pm 0.28$ \\
Hind-foot & & & \\
Length & 10 & $5.19-6.18$ & $5.47 \pm 0.38$ \\
Width & 10 & $4.08-4.32$ & $4.16 \pm 0.09$ \\
Trail & & & \\
Step & 6 & $5.42-12.88$ & $7.85 \pm 3.21$ \\
Stride & 5 & $24.5-35.26$ & $31.5 \pm 4.42$ \\
Straddle & 4 & $5.39-10.48$ & $7.96 \pm 2.08$ \\
\hline
\end{tabular}

Table 1. List of small-clawed otter signs in the UCPS Hydropower

\begin{tabular}{|c|c|c|c|c|c|c|c|c|}
\hline \multirow{2}{*}{ Date } & \multicolumn{4}{|c|}{ Signs } & \multirow{2}{*}{$\begin{array}{l}\text { Individual } \\
\text { estimation }\end{array}$} & \multirow{2}{*}{$\begin{array}{l}\text { Number of } \\
\text { Individuals }\end{array}$} & \multirow{2}{*}{ Group } & \multirow{2}{*}{ Additional Information } \\
\hline & Fe & Fo & D & CT & & & & \\
\hline Citali River & & & & & & $1-5$ & $1 \mathrm{st}$ & \\
\hline 7/02/2017 & & + & & & 1 & & & Ten footprints \\
\hline $7 / 02 / 2017$ & & + & & & 2 & & & 24 footprints \\
\hline $7 / 02 / 2017$ & & + & & & 2 & & & 13 footprints \\
\hline $7 / 02 / 2017$ & + & & & & 2 & & & Age: $<5$ hours; Mixed-form; Diameter: $24.3 \mathrm{~cm}$ \\
\hline $11 / 02 / 2017$ & + & & & & 1 & & & Age: 11 hours; Spread-form; Diameter: $18.6 \mathrm{~cm}$ \\
\hline $12 / 02 / 2017$ & + & & & & 2 & & & Age: three days; Spread-form; Diameter: 26.7 cm \\
\hline $14 / 02 / 2017$ & + & & & & 1 & & & Age: less than a day, Spread-form, Diameter: $25.6 \mathrm{~cm}$ \\
\hline $14 / 02 / 2017$ & & + & & & 1 & & & Three footprints \\
\hline $14 / 02 / 2017$ & + & & & & 1 & & & Age: One month, Spread-form, Diameter: Uncountable \\
\hline $17 / 02 / 2017$ & & + & & & 1 & & & One footprint \\
\hline $17 / 02 / 2017$ & & + & & & 1 & & & One footprint \\
\hline $17 / 02 / 2017$ & & + & & & 1 & & & Four footprints \\
\hline 18/02/2017 & & & + & & 2 & & & Inactive \\
\hline \multicolumn{9}{|l|}{ Cisokan River } \\
\hline $13 / 02 / 2017$ & & & + & & $1-4$ & & & Active \\
\hline $13 / 02 / 2017$ & & & & + & 5 & & & 349 photo captured \\
\hline $18 / 02 / 2017$ & + & & & & 3 & & & Age: two weeks; Spread-form, Diameter: $36.2 \mathrm{~cm}$ \\
\hline Cilengkong River & & & & & & $1-2$ & 2nd & \\
\hline $14 / 03 / 2017$ & + & & & & 1 & & & Age: two weeks; Spread-form; Diameter: $9.49 \mathrm{~cm}$ \\
\hline $14 / 03 / 2017$ & + & & & & 1 & & & Age: two days; Spread-form; Diameter: $18.5 \mathrm{~cm}$ \\
\hline $14 / 03 / 2017$ & & & + & & 2 & & & Inactive \\
\hline $15 / 03 / 2017$ & + & & & & 1 & & & Age: one days; Bolus-form; Diameter: $3.9 \mathrm{~cm}$ \\
\hline $15 / 03 / 2017$ & + & & & & 1 & & & Age: less than four hours; Bolus-form; Diameter: $8.9 \mathrm{~cm}$ \\
\hline $19 / 03 / 2017$ & + & & & & 2 & & & Age: two weeks; Spread-form; Diameter: $20.2 \mathrm{~cm}$ \\
\hline $19 / 03 / 2017$ & + & & & & 3 & $1-3$ & $3 \mathrm{rd}$ & Age: three weeks; Spread-form; Diameter: $16.2 \mathrm{~cm}$ \\
\hline $19 / 03 / 2017$ & + & & & & 2 & & & $\begin{array}{l}\text { Age: four days, two days, and one day (different ages of } \\
\text { feces in one spot), Mixed-form; Diameter: } 35.8 \mathrm{~cm}\end{array}$ \\
\hline $19 / 03 / 2017$ & + & & & & 2 & & & Age: less than a day, Bolus-form; Diameter: $32.7 \mathrm{~cm}$ \\
\hline $20 / 03 / 2017$ & + & & & & 1 & & & Age: 3-4 days; Spread-form; Diameter: $8 \mathrm{~cm}$ \\
\hline $20 / 03 / 2017$ & & + & & & 1 & & & Three footprints \\
\hline $20 / 03 / 2017$ & + & & & & 2 & & & $\begin{array}{l}\text { Age: two days \& less than a day; Bolus-form; Diameter: } \\
67.8 \mathrm{~cm}\end{array}$ \\
\hline $20 / 03 / 2017$ & + & & & & 1 & & & $\begin{array}{l}\text { Age: two weeks \& four days; Spread-form; Diameter: } \\
22.4 \mathrm{~cm}\end{array}$ \\
\hline \multicolumn{9}{|l|}{ Cirumamis River } \\
\hline $10 / 04 / 2017$ & + & & & & 1 & $1-3$ & 4th & Age: three days; Spread-form; Diameter: $13.3 \mathrm{~cm}$ \\
\hline $10 / 04 / 2017$ & + & & & & 2 & & & Age: three days; Spread-form; Diameter: $6.8 \mathrm{~cm}$ \\
\hline $10 / 04 / 2017$ & + & & & & 3 & & & Age: less than a day; Spread-form; Diameter: $19.7 \mathrm{~cm}$ \\
\hline $14 / 04 / 2017$ & + & & & & 1 & 1 & 5 th & Age: less than a day; Bolus-form; Diameter: $18.9 \mathrm{~cm}$ \\
\hline
\end{tabular}

Note: Fe: Feces; Fo: Footprint; D: Dens; CT: Camera Trap 
Table 3. General characteristics of small-clawed otter dens

\begin{tabular}{|c|c|c|c|}
\hline Parameter & $\begin{array}{c}\text { Active } \\
\text { (Cisokan River) } \\
\end{array}$ & $\begin{array}{c}\text { Inactive } \\
\text { (Citali River) }\end{array}$ & $\begin{array}{c}\text { Inactive } \\
\text { (Cilengkong River) }\end{array}$ \\
\hline \multirow[t]{2}{*}{ Hole size } & Height: $20 \mathrm{~cm}$ & Height: $15 \mathrm{~cm}$ & Height: $12 \mathrm{~cm}$ \\
\hline & Width: $54 \mathrm{~cm}$ & Width: $33 \mathrm{~cm}$ & Width: $20 \mathrm{~cm}$ \\
\hline Composition & Rocky & Rocky & Rocky \\
\hline Land cover type & Agroforestry & Agroforestry & Agroforestry \\
\hline Slope & Steep & Sloping & Sloping \\
\hline Elevation & $511 \mathrm{~m}$ asl & $545 \mathrm{~m}$ asl & $628 \mathrm{~m}$ asl \\
\hline Temperature & $28^{\circ} \mathrm{C}$ & $27.8^{\circ} \mathrm{C}$ & $29.5^{\circ} \mathrm{C}$ \\
\hline Humidity (09.00 WIB) & $88.6 \%$ & $87.3 \%$ & $84 \%$ \\
\hline Distance from the riverbank & $29.75 \mathrm{~m}$ & $0.8 \mathrm{~m}$ & $4 \mathrm{~m}$ \\
\hline The elevation above the river surface & $22 \mathrm{~m}$ & $0.23 \mathrm{~m}$ & $2.3 \mathrm{~m}$ \\
\hline Signs around the dens & $\begin{array}{l}\text { Footprints and feces (less than } \\
\text { one day of age) }\end{array}$ & $\begin{array}{l}\text { Dried feces and not fully } \\
\text { printed footprints }\end{array}$ & Dried feces \\
\hline
\end{tabular}

Table 4. Preference of small-clawed otter habitat based on signs

\begin{tabular}{lcccc}
\hline \multicolumn{1}{c}{ Land Cover } & \multicolumn{1}{c}{ Signs } & Dens & \multirow{2}{*}{$\%$} \\
\cline { 2 - 5 } & Feces & Footprints & 0 & 43.75 \\
Paddy Field & 13 & 1 & 3 & 43.75 \\
Agroforestry & 5 & 6 & 0 & 9.38 \\
Shrubs & 2 & 1 & 0 & 3.13 \\
Natural Forest & 1 & 0 & 0 & \\
\hline
\end{tabular}

Table 5. Location and time of camera trap installation

\begin{tabular}{|c|c|c|c|c|c|c|}
\hline Code & Period & $\begin{array}{c}\text { Trap } \\
\text { nights }\end{array}$ & River & Land cover & \multicolumn{2}{|c|}{ Coordinate } \\
\hline CT 1 & Feb. 11-Mar. 7 & 24 & Citali River & Agroforestry & $6^{\circ} 58^{\prime} 03.81^{\prime \prime}$ & $107^{\circ} 12^{\prime} 44.58^{\prime \prime}$ \\
\hline CT 2 & Feb. 14-Mar. 7 & 21 & Cisokan River & Agroforestry & $6^{\circ} 57 ' 57.74 "$ & $107^{\circ} 11^{\prime} 40.68^{\prime \prime}$ \\
\hline CT 3 & Feb. 11-Mar. 7 & 24 & Citali River & Agroforestry & $6^{\circ} 57^{\prime} 55.39^{\prime \prime}$ & $107^{\circ} 12^{\prime} 38.12^{\prime \prime}$ \\
\hline CT 4 & Feb. 11-Mar. 7 & 24 & Citali River & Agroforestry & $6^{\circ} 58^{\prime} 04.54 "$ & $107^{\circ} 12^{\prime} 42.98^{\prime \prime}$ \\
\hline CT 5 & Mar. 14-Apr. 4 & 21 & Cilengkong River & Agroforestry & $6^{\circ} 56^{\prime} 22.32^{\prime \prime}$ & $107^{\circ} 14^{\prime} 21.63^{\prime \prime}$ \\
\hline CT 6 & Mar. 15-Apr. 4 & 20 & Cilengkong River & Paddy field & $6^{\circ} 56^{\prime} 15.26^{\prime \prime}$ & $107^{\circ} 14^{\prime} 29.64^{\prime \prime}$ \\
\hline CT 7 & Mar. 16-Apr. 4 & 19 & Cilengkong River & Paddy field & $6^{\circ} 56^{\prime} 09.72^{\prime \prime}$ & $107^{\circ} 14^{\prime} 44.14^{\prime \prime}$ \\
\hline
\end{tabular}

\section{Citali-Cisokan River}

The Cisokan River is a tributary of the Citarum River that flows from south to north and ends into the Java Sea. The Cisokan River has a width of 20-30 meters, a depth of $30-150 \mathrm{~cm}$, and has a heavy water flow. This river connects the lower and upper dam construction area of the UCPS Hydropower through several connected tributaries, including the Citali River and the Cilengkong River. The flow consists of pools (no flow), riffles (turbulent flow over rocks), and runs (smooth and non-turbulent flow). In the particular river, areas have a substrate of gravel, large stones, and bedrocks. There are various land-use types along the Cisokan river, including talun/agroforestry, pine forest, natural forest, paddy fields, shrubs, settlements, and open land. The abundance of agroforestry, paddy fields, and ponds around this stream indicates that the Cisokan River is the primary water source utilized by the settlements.

The Citali River is a tributary that ends directly into the Cisokan River. The river has a width of 2-10 meters, a 15$90 \mathrm{~cm}$ depth, and a moderate water discharge. The flow consists of riffles (turbulent flow over rocks) and runs (smooth and non-turbulent flow). The substrate of this river consists of sand, gravel, and large stones. The middle part of the river has a depth of 1.5-2 meters, and the other part is steeply contoured to near the upstream. Land cover types around the Citali River, including settlements, paddy fields, ponds, agroforestry, and natural forest.

Based on Table 1, the number of individuals based on the footprints (Figure $3 F$ ) is estimated at 1-2 individuals, as indicated by the presence of two different trails. This finding was confirmed by the differences in the feces form found with mixed-form (3-4 bolus with a diameter of 24.3$26.7 \mathrm{~cm}$ ). Another finding, spread-form feces was found with a diameter of $36.3 \mathrm{~cm}$, representing 1-3 individuals.

Based on the dens (Table 1), it consisted of inactive and active dens. The inactive den (Figure 3E) was assumed to be inhabited by the two small-clawed otter individuals. The assumption is that the number is determined based on the size of the den hole, which is relatively tiny (height: $15 \mathrm{~cm}$ and width: $33 \mathrm{~cm}$ ) and is used to find prey around the den. Active dens are assumed to be inhabited by a maximum of 
four individuals, with a large enough den hole size (height: $20 \mathrm{~cm}$ and width: $54 \mathrm{~cm}$ ) and a long corridor. In front of the active den, spread-form feces and several footprints are found. The finding of active den could strengthen previous assumptions regarding the estimated number of individuals based on signs. Based on the assumptions of the signs and den, the estimated number of individuals along the CitaliCisokan River is 1-4 individuals.
Based on a camera trap, one group (five individuals) was found in the Citali-Cisokan River. The number of individuals in the observed group is the average individual in one small-clawed otter group. According to Kruuk (2006), it can increase up to 15 individuals. The recording results strengthen the analysis of individual estimates based on signs and dens. It is concluded that the individual estimates along the Citali-Cisokan River are 1-5 individuals in one group (Figure 3C and 3D).
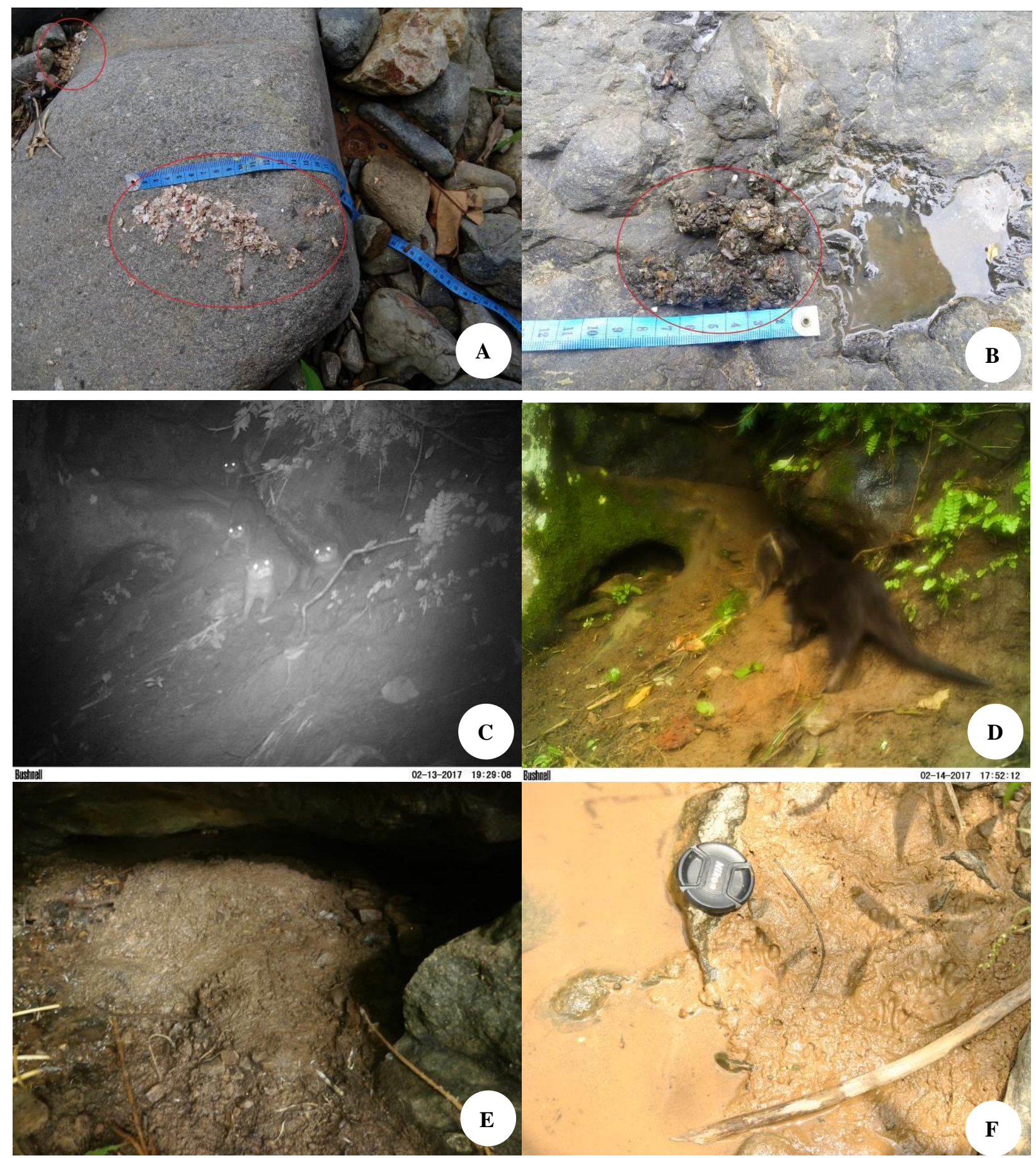

Figure 3. The Asian small-clawed otter in the UCPS Hydropower, Cianjur. A. Dried feces, B. Bolus-form feces, C. Active den in the Citali River, D. The activity of maternal-infant, E. Inactive den in the Citali River, F. Footprints in the Citali River. 


\section{Cilengkong River}

Cilengkong River is a tributary of the Cirumamis River. This river has a width of 3-15 meters, a depth of 20-120 $\mathrm{cm}$, and the water discharge is from moderate to rather large water flow. The river flow consists of pools (no flow), riffles (turbulent flow over rocks), and runs (smooth and non-turbulent flow). The Cilengkong river substrate consists of sand, gravel, large stones, and bedrocks near the waterfall/curug. The land-use types found along the river are paddy fields, ponds, agroforestry, settlements, shrubs, and open land. In the river flow, there are two waterfalls, namely Curug Kuda and Curug Munding.

The existence of small-clawed otters along the river flow is known based on signs and inactive den. The Cilengkong River is divided into the Cilengkong River estuary to the Curug Munding (lower) and the Curug Munding to the bridge (upper). The dividing of the Cilengkong River is due to geographical conditions, where the Curug Munding has a height of \pm 45 meters and a slope of $60^{\circ}-75^{\circ}$ so that the movement of the small-clawed otter is quite limited and cannot move to the upper river or vice versa in a short time. It is assumed that there are two smallclawed small-clawed otter groups in the Cilengkong River.

Just like the Citali-Cisokan River, the feces mainly were found compared to other signs. Based on the findings of five feces and inactive den, the number of small-clawed otter individuals is assumed to be 1-2 individuals at the lower of the Cilengkong River. The count of one individual was obtained from feces in the bolus form (Figure 3B) and spread-form (consisting of 1-5 bolus with a diameter of $3.2-18.5 \mathrm{~cm})$. In other findings, there were spread-form feces with diameters of $8 \mathrm{~cm}$ and $12.2 \mathrm{~cm}$, representing two small-clawed otter individuals. The existence of these two individuals is confirmed through an inactive den (height: $12 \mathrm{~cm}$; width: $20 \mathrm{~cm}$ ), which is assumed to have been inhabited by two individuals.

In the upper Cilengkong River, it is assumed that there are 1-3 individuals based on the findings of six feces and one footprint. The estimation of one individual was obtained from the findings of spread-form feces (diameter of 6.3-16.1 cm), which were assumed as the same individual. In other signs, the feces were found in spreadform (diameter of $18 \mathrm{~cm}$ ) and bolus-form (length of 2.1$29.5 \mathrm{~cm}$ ), representing two small-clawed otter individuals. Signs that indicate two individuals are known from feces forms, colors, and restricted distribution. Another individual was obtained from observing spread-form feces (diameter of $16.2 \mathrm{~cm}$ ) at the edge of the paddy fields.

\section{Cirumamis River}

Cirumamis River is a tributary of the Cisokan River with a width of 2.5-10 meters, $25-250 \mathrm{~cm}$, and a large water discharge. The river flow consists of pools (no flow), riffles (turbulent flow over rocks), and runs (smooth and non-turbulent flow). Cirumamis River substrate consists of sand, gravel, large stones, and bedrocks in certain parts of the river. The land-use types surround this river, including natural forest, paddy fields, shrubs, swidden cultivations/fields, ponds, and agroforestry. In the middle of the river, there are two curug, namely Curug Walet and Curug Japarana. In this study, the Cirumamis River is divided into two parts: the flow leading to Curug Walet to Curug Japarana (upper) and Cirumamis River estuary to the bottom part of Curug Walet (lower). The dividing of the Cirumamis River into two parts is due to the geographical barrier of Curug Walet $( \pm 125$ meters height and a slope of nearly $90^{\circ}$ ), thus limiting the small-clawed otter's movement.

The lower part of the Cirumamis River is estimated as a single individual. The estimation was obtained based on finding one bolus-form feces (length of $3.1 \mathrm{~cm}-6.9 \mathrm{~cm}$ ). Meanwhile, in the upper part of the Cirumamis River, it is estimated that there are 1-3 individuals from the three findings of feces. This estimate was obtained from a single individual's findings of spread-form feces (diameter of 6.8 $\mathrm{cm}$ ). Another finding, spread-form feces (diameter of 13.3 $\mathrm{cm}$ ), represents two individuals. Previous assumptions were strengthened by the findings of feces (diameter of $19.7 \mathrm{~cm}$ ) which were assumed to represent three individuals. We considered the age of feces (three days of age) and adjacent feces placement. We assume that these 1-3 individuals belong to one group.

We summarized five groups of small-clawed otters in the UCPS hydropower plant area (Table 1). The first group was distributed in the Citali-Cisokan River. A total of 1-5 individuals was analyzed based on differences of trails, feces form, and latrine site diameter, inactive and active dens findings, and confirmed findings through camera trap. In the Cilengkong River, the second (1-2 individuals) and third group (1-3 individuals) were analyzed based on the geographical barrier (waterfall or curug), differences of feces form and diameter, and inactive den. Similar to groups in the Cilengkong River, the fourth (1-3 individuals) and fifth group (single individual) were divided cause of geographical barriers (waterfall). Besides, these groups were analyzed based on feces form, latrine site diameter, age of feces.

\section{Overlapping habitat with the UCPS Hydropower}

In pre-construction, land acquisition has been carried out for the UCPS Hydropower development area, especially rice fields and ponds, to dry the land. This dry land has the potential for habitat loss for small-clawed otters and reduced prey sources. At the construction stage, one of which is constructing an access road that can cause landslides due to land clearing using explosives. This landslide can block small-clawed otters' den holes, such as in Curug Kunti, Pasir Nangka.

If seen in Figure 2, several locations of small-clawed otters are known to overlap with the hydropower development area. An active den inhabited by four individuals and one infant in the Cisokan River can be lost in a lower dam area. This group of small-clawed otters will undoubtedly leave the den to look for a habitat far from the hydropower development. The worst possibility is the potential to die due to construction activities. Some locations with feces and footprints can be lost, resulting in limited access to food sources and reduced food sources. 
Not only does the location overlap with the dam, but the small-clawed otter habitat found in the Cirumamis River (outside the dam) also has the potential to be lost, especially access to food. Several infrastructures will be built around the Cirumamis and Cilengkong Rivers, such as spoil bank, plant and yard, camp and site office, access tunnels, and access roads.

By knowing this condition, it is necessary to further monitor the presence of small-clawed otters during construction and post-construction. Further observations are needed regarding the extent to which otter groups will move away from the construction area. Future studies should examine factors allowing persistence of smallclawed otters in different human-modified land-uses and the impact of damming on the distribution and occurrence of small-clawed otters (Punjabi et al. 2014). Besides, it is necessary to implement a biodiversity management plan such as a management plan written by Meijaard and Ferguson (2014), LPPM Unpad (2014 unpublished), Husodo et al. (2019) to support the small-clawed otter habitat in addition to the construction of the UCPS hydropower plant.

It can be concluded that part of UCPS Hydropower area is the habitat of the small-clawed otter. The estimated population size of the small-clawed otter at the UCPS Hydropower ranges from 5-14 individuals distributed in the Citali-Cisokan, Cilengkong, and Cirumamis rivers. In addition, the discovery of infant and sleeping mat repairing activities also shows that the habitat in the UCPS Hydropower area supports the daily needs of the smallclawed otter. Further studies are needed regarding the impact of the UCPS Hydropower development on the existence of small-clawed otters. Further observations are needed regarding the extent to which otter groups will move away from the construction area. One of the conservation strategies that can be implemented is making wildlife management policies to support small-clawed otter habitats and develop UCPS hydropower.

\section{ACKNOWLEDGEMENTS}

Acknowledgments were given to the Indonesian State's Electricity Company (PT. PLN Persero) Unit Induk Pembangunan IV, Rector through Academic Leadership Grant Program Padjadjaran University (2016-2017)-Prof. Erri Noviar Megantara, and Center Environment for Sustainability Science (CESS) Padjadjaran University. We are grateful to Erik Meijaard, Pene Ferguson, the expertise, the surveyor team, and the local people.

\section{REFERENCES}

Aadrean, Usio N. 2017. Small-clawed otters (Aonyx cinereus) in Indonesian rice fields: Latrine site characteristics and visitation frequency. Ecol Res 32 (6): 899-908. DOI: 10.1007/s11284-0171496-6

Aadrean, Usio N. 2020. Spatiotemporal petterns of latrine-site use by small-clawed otters in a heterogeneous rice field landscape. Mamm Stud 45 (2): 103-110. DOI: 10.3106/ms2019-0031
Abdul-Patah P, Nur-Syuhada N, Md-Nor S, Sasaki H, Md-Zain BM. 2014. Habitat and food resources of otters (mustelidae) in peninsular Malaysia. AIP Conf Proc 1614: 693-699. DOI: 10.1063/1.4895286

Almeida D, Copp GH, Masson L, Miranda R, Murai M, Sayer CD. 2012. Changes in the diet of a recovering Eurasian otter population between the 1970s and 2010. Aquat Conserv Mar Freshw Ecosyst 22: 26-35. DOI: $10.1002 / \mathrm{aqc} .1241$

Andeska F, Novarino W, Nurdin J, Aadrean. 2021. Relationship between temporal environment factors and diet composition of small-clawed otter (Aonyx cinereus) in heterogeneous paddy fields landscape in Sumatra, Indonesia. IUCN Otter Spec Group Bull 38 (2): 106-116.

Barocas A, Golden HN, Harrington MW, McDonald DB, Ben-David M. 2016. Coastal latrine sites as social information hubs and drivers of river otter fission-fusion dynamics. Anim Behav 120: 103-114. DOI: 10.1016/j.anbehav.2016.07.016

Che SMR, Siregar AZ, Abu HA, Nasution Z. 2017. Dynamics of aquatic organisms in a rice field ecosystem: effects of seasons and cultivation phases on abundance and predator-prey interactions. Trop Ecol 58 (1): 177-191.

Cianfrani C, Le Lay H, Maiorano L, Satizábal HF, Loy A, Guisan A. 2011. Adapting global conservation strategies to climate change at the European scale: the otter as a flagship species. Biol Conserv 144: 2068-2080. DOI: 10.1016/j.biocon.2011.03.027

Fei Li, Chan BPL. 2017. Past and present: The status and distribution of otters (Carnivora: Lutrinae) in China. Oryx 52 (4): 619-626. DOI: $10.1017 / \mathrm{S} 0030605317000400$

Glatston A, Duplaix N. 2020. Introduction: Conservation of small carnivores. Intl Zoo Yb 54: 11-18. DOI: 10.1111/izy.12282

Gomez L, Shepherd CR. 2018. Smooth-coated Otter Lutrogale perspicillata receives formal protection in Indonesia, but smallclawed otter Aonyx cinereus does not. IUCN Otter Spec Group Bull 35 (2): 128-130.

Green ML, Monick K, Manjerovic MB, Novakofski J, Mateus-Pinilla N. 2015. Communication stations: Cameras reveal river otter (Lontra canadensis) behavior and activity patterns at latrines. J Ethol 33: 225 234. DOI: $10.1007 / \mathrm{s} 10164-015-0435-7$

Hon N, Neak P, Khov V, Cheat V. 2010. Food and habitat of Asian smallclawed otters in Northeastern Cambodia. IUCN Otter Spec Group Bull 27 (1): 12-23.

Husodo T, Shanida SS, Megantara EN. 2019. Biodiversity management plan in the non-conservation area, Cisokan Hydropower plan area, Cianjur, West Java, Indonesia. Biodiversitas 20 (6): 1524-1536. DOI: 10.13057/biodiv/d200606

Hussain SA, Gupta SK, de Silva PK. 2011. Biology and ecology of Asian small-clawed otter Aonyx cinereus (Illiger, 1815): A review. IUCN Otter Spec Group Bull 28 (2): 63-75.

Jansen PA, Travis DF, McShea WJ. 2014. Protocol for Camera Trap Surveys of Mammals at CTFS-ForestGEO Sites ver 1.1. Smithsonian Tropical Research Institute, Panama.

Kanchanasaka B, Duplaix N. 2011. Food habits of the hairynosed otter (Lutra sumatrana) and the small-clawed otter (Aonyx cinereus) in Pru Toa Daeng Peat Swamp Forest, Southern Thailand. IUCN Otter Spec Group Bull 28A: 139-149.

Krpo-ćetković J, Subotić S, Skorić S, Ćirović D. 2019. Diet of the Eurasian otter (Lutra lutra) on the River Gradac, Serbia: Predation in a brown trout-dominated stream. Aquat Conserv Mar Freshw Ecosyst 29: 282-291. DOI: 10.1002/aqc.3013

Kruuk H. 2006. Ecology, Behaviour and Conservation. Oxford University Press Inc, New York.

LPPM Unpad (Research and Community Service Institution Padjadjaran University). 2014. Biodiversity Management Plan Upper Cisokan Pumped Storage Report. PT PLN (Persero) and LPPM-PPSDAL Universitas Padjadjaran, Bandung. [Indonesian] [Unpublished data]

Margono BA, Potapov PV, Turubanova S, Stolle F, Hansen MC. 2014. Primary forest cover loss in Indonesia over 2000-2012. Nat Clim Chang 4: 1-6. DOI: 10.1038/NCLIMATE2277

Meijaard E, Ferguson P. 2014. Biodiversity management plan upper Cisokan pumped storage. [Technical Report]. PT PLN (Persero)Development Master Unit-UIP VI and Padjadjaran University, Bandung.

Melisch R, Asmoro PB, Kusumawarhdani L. 1994. Major steps taken towards otter conservation in Indonesia. IUCN Otter Spec Group Bull 10: $21-24$.

Menzies RK, Rao M. 2021. Short communication: Incidental sightings of the vulnerable Asian small-clawed otter (Aonyx cinereus) in Assam, 
India: current and future threats. IUCN Otter Spec Group Bull 38 (1): $38-44$.

Okamoto Y, Maeda N, Hirabayashi M, Ichinohe N. 2020. The situation of pet otters in Japan-warning by vets. IUCN Otter Spec Group Bull 37 (1): 71-79.

Perinchery A, Jathanna D, Kumar A. 2011. Factors determining occupancy and habitat use by Asian small-clawed otters in the Western Ghats, India. J Mamm 92: 796-802. DOI: 10.1644/10 MAMM-A-323.1

Prakash N, Mudappa D, Raman TRS, Kumar A. 2012. Conservation of the Asian small-clawed otter (Aonyx cinereus) in human-modified landscapes, Western Ghats, India. Trop Conserv Sci 5: 67-78. DOI: 10.1177/194008291200500107

Punjabi GA, Borker AS, Mhetar F, Joshi D, Kulkarni R, Alave SK, Rao MK. 2014. Recent records of stripe-necked mongoose Herpestes vitticolis and Asian small-clawed otter Aonyx cinereus from the north Western Ghats, India. Small Carnivore Conserv 51: 51-55.

Raha A, Hussain SA. 2016. Factors affecting habitat selection by three sympatric otter species in the southern Western Ghats, India. Acta Ecol Sin 36: 45-49. DOI: 10.1016/j.chnaes.2015.12.002
Sanghamithra D, Nameer PO. 2018. Small carnivores of Silent Valley National Park, Kerala, India. J Threatened Taxa 10 (8): 12091-12097. DOI: 10.11609/jott.2992.10.8.12091-12097

Timm-Davis LL, De Witt TJ, Marshall CD. 2015. Divergent skull morphology supports two trophic specializations in otters (Lutrinae). Plos one 10: 2-3. DOI: 10.1371/journal.pone.0143236

UNEP-WCMC (Comps.) 2021. Checklist of CITES Species. CITES Secretariat, Geneva, Switzerland and UNEP-WCMC, Cambridge, United Kingdom.

van Strien NJ. 1983. Guide to the Track of Mammals of Western Indonesia. School of Environmental Conservation Management, Ciawi.

Wright L, de Silva P, Chan B, Lubis IR. 2015. Aonyx cinereus. IUCN Red List Threatened Spec 2015: e.T44166A21939068. DOI: 10.2305/IUCN.UK.2015-2.RLTS.T44166A21939068.en

Wright LC. 2005. Interesting cooperative bedding gathering behaviour in captive Asian small-clawed otters (Amblonyx cinerea). IUCN Otter Spec Group Bull 18 (1): 25-28. 